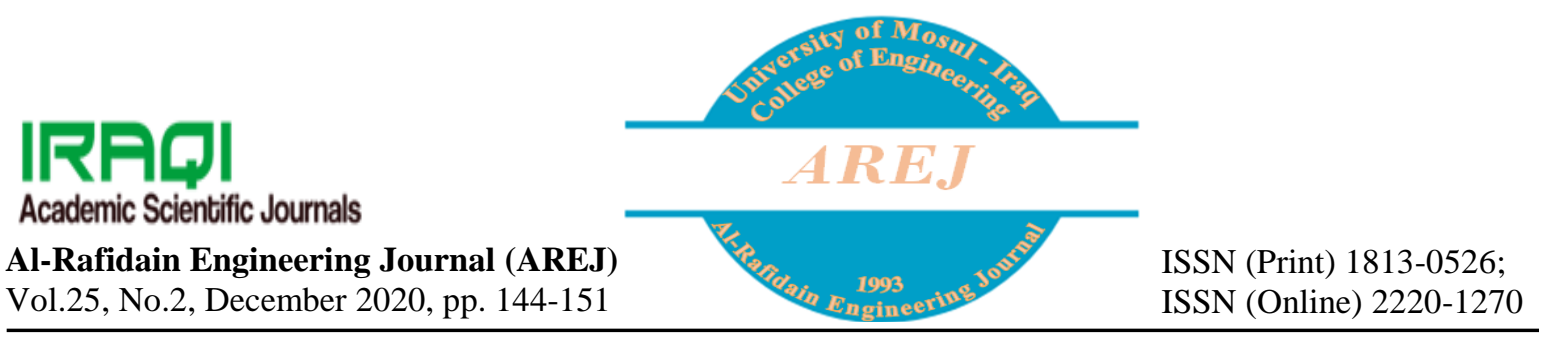

\title{
Weighting Signal Error Reduction
}

\author{
Abdelkader Faris Abdelkader \\ abdlkaderfares52@gmail.com
}

\author{
Fakhrulddin Hamid Ali \\ fhazaa@uomosul.edu.iq
}

Computer Engineering Department, Collage of Engineering, University of Mosul

\begin{abstract}
The paper presents and discusses how to use some techniques to reduce the effect of error in the weighting signal which is produced from a load cell. The load cell is one of succeful sensors which is used to transform the weight to an electrical signal. In industry the production of an accurate signal suffers from a problem of noisy environment. Different source of noise like electromagnetic fields from motors, machines, power lines and microwave in addition to humidity and tempreture variations have significant effects on weak electrical signals produced by load cells.Both hardware and software filtering are adopted to reduce the un wanted effects.
\end{abstract}

Keywords:

Loadcell; Arduino; Differential signal; ADC converter; Instrumentation Amplifier

https://rengj.mosuljournals.com

Email: alrafidain_engjournall@uomosul.edu.iq

\section{INTRODUCTION}

In our time the industry world had seen great development and produce many products they need more development in the weight measurements such as asphalt industry and pharmaceutical industry there are group of sensors and transformers such as load cell used for the purpose of tracking and determining the accurate components of the objects during moving over conveyor belt [1] [2] as shown in figure (1).

The load cell sensor which is used for this purpose consists of strain guages as sensing elements [3]. The strain gauge converts the deformation to electrical signal where the resistance variation in the strain gauge is proprortional to the magnitude of the applied force [4]. In general the load cell consists of four strain gauges in a wheatston bridge configuration to sense the weight. The wheatstonbridge achieves minimum possible deviation between the output and the ideal output voltage [5].
The load cell is used in many fields such as weighing measurement like food, fuel, cement, vehical, animals, gripper of arobotic arm. The load cell produces a very weak signal in mille volt and makes it vulnerable to any out side un-wanted signal such as noise, temperature vibration, electromagnetic interferences and high humidity effect. Some strategies has to be used to reduce the error in weighting signal. Because the out put signal from load cell is very weak in mille-volt and we want to convert it to digital whereas the $\mathrm{ADC}$ input is in volt range. It is very necessary to use instrumentation amplifier to enlarge the signal and make it suitable for ADC.The instrumentation amplifier used in our system is AD620 its properties are low drifft high gain and high CMRR[6] as shown in figure(3).

The signal after being amplified using instrumentation amplifier AD620 chip enter the arduino node mcu $32 \mathrm{~s}$ it has internal ADC $12 \mathrm{bit}$ as shown in figure(3)[7] to convert it to digital. The digital output is varied as a result of noise affect. So it the out put has a range from 
minimum to maximum range which needs to be reduced. So the output varies between minimum to maximum. This range of variations needs to be reduced.
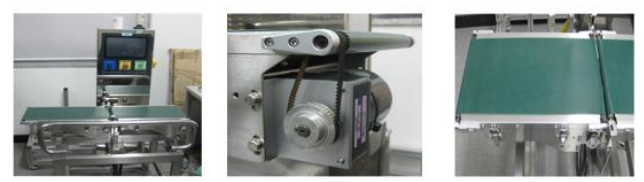

Weighing machine.

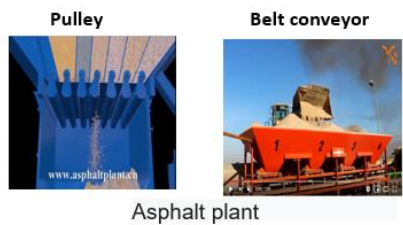

Figure (1).Weighing in motion [3].

\section{Theory}

Several measures have been conducted to reduce the noise effect some of them are stated in this article

\subsection{Shielded Cables}

One method to reduce the common mode electrostatic noise and prevents it from affecting the signal inside the cable by connecting one end of shield to GND in this case we prevent ground loop from forming.

\subsection{Grounding}

To ensure that all circuit in system has same reference potential we build a ground plane to reduce noise where every point on its surface is at the same potential. The ground plane makes low impedance ground fault return path to the power source where the analog ground is connected to the digital ground. In this method the ground noise effect is minimized [8].

\subsection{Twisted Pair Cables}

The same current flow in a pair in opposite direction so any noise add to the signal will add in both direction therefore,one cancels each other[9]. In this way we reduce the effect of noise on the signal as shown in figure (2).

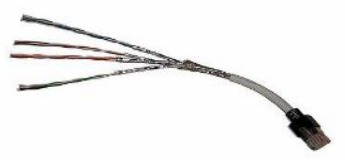

Figure (2).Twisted pair[9].

\subsection{Wire Routing}

This technique is used in order to keep high voltage power and motor wiring noise from affecting low voltage signal wiring. Which is done by separating low voltage wires from high voltage wires through free air using tray dividers. It is essential for keep signal integrity [2]. This is important when using the system in industrial environment.

\section{Previous Work}

Since the need to pay attention to the signal which is produced from the Load cell and reduces its error resulting from the noise, the researchers began proposing and presenting ideas to reduce the noise, and from a set of previous ideas, some suggestions and actions are reviewed.

P. Castellini (2002) proposed the "AntiAliasing Filter". This filter removes noise at frequencies above the ant-aliasing filter cutoff frequency.The cutoff frequency can be determinined by the sample rate for a data acquisition system which is twice the maximum frequency of interest according to the Nyquist sampling theorem. Anti-aliasing filters can be implemented in software using over sampling [1].

Kyoo Nam choi (2011) proposed "Variable cutoff frequency and slope LpF" which consisted from two stages the first stage is L.P.F for cutoff frequency variable to reject peak noise components the next stage is six lpf for slope control and obtaining pulse width ratio during the remove of un wanted noise spectrum[2]

RajeshDey, AtreyeeBiswas Suman kumarLaha ,Amlan pal and DR.Achintya Das (2014) proposed the "Signal Correction of load cell output using Adaptive Method" that consists of no.of stages the first stage has two missions they are producing mathematical model of a load cell and takes digitized output of load cell by entering to ADC. The adaptive techniques minimize the oscillation in output and also from the digital data converted to analog by DAC [10].

John frank (2017) present" weight controller equipped with analog low _pass 
filter". The Lpf removes random jitter and produces analog averaging close to the original signal. The mission of weight controller equipped with adual_slope, ADC, is digitizing the signal and takes the average for the readings and produces smooth signal [4].

\section{Proposed and implemented work}

A simple block diagram of the current system is illustraited in figure (3).

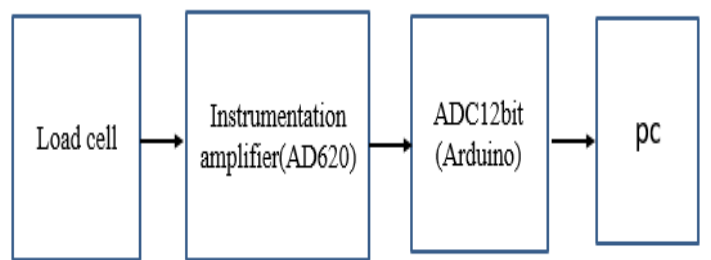

Figure (3). Schematic of basic system block diagram..

As the beginning, the load cell must be checked which is used in the current system if it is linear or non linear. By appling the loads from $100 \mathrm{~g}$ to $20 \mathrm{~kg}$ and record the output voltage from Load cell using digital voltemeter with high accuracy (two digits after decimal in millivolt range).

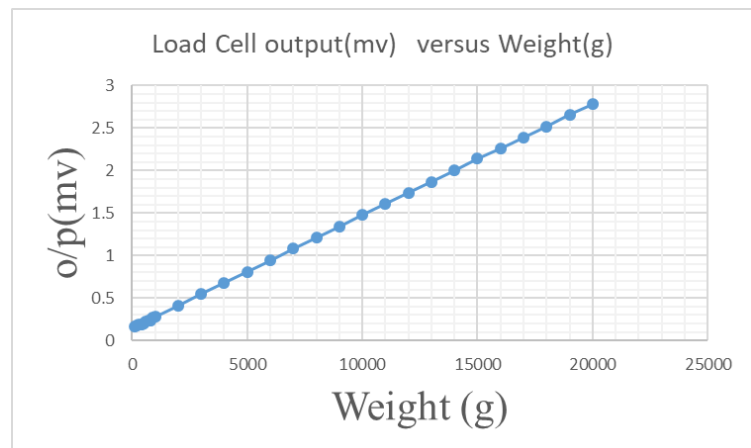

Figure (4) Load cell linearity.

After the linearity test of the used load cell the over all system is tested and its output is measured at different loads according to the flow chart given.
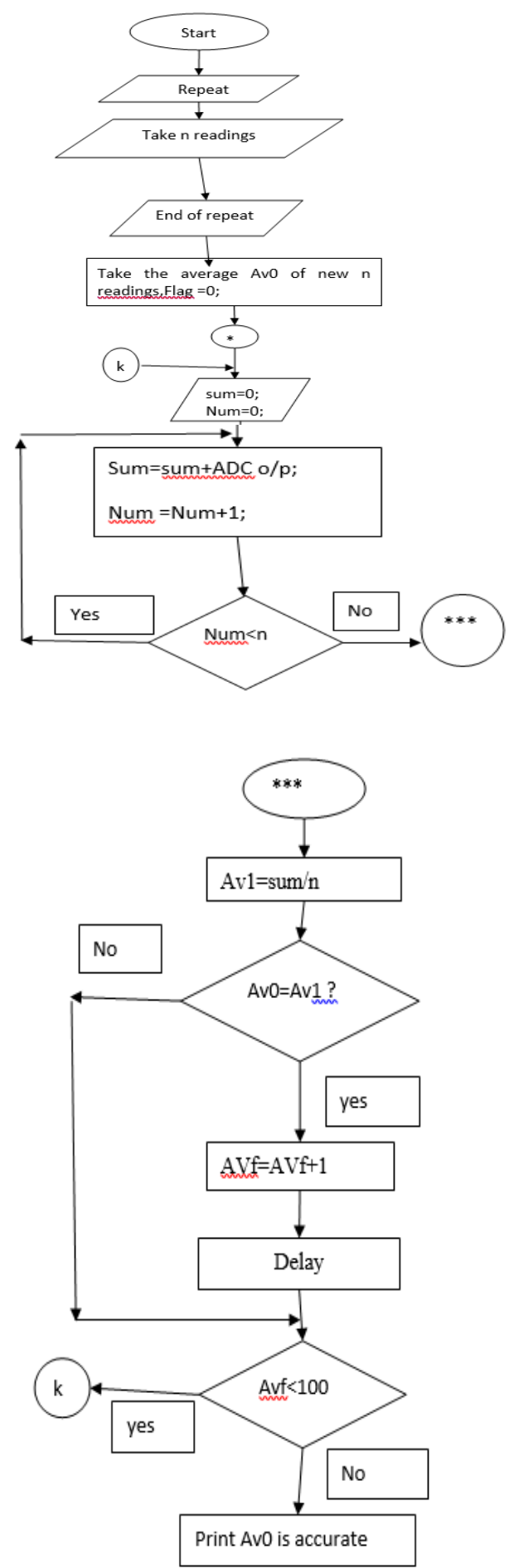


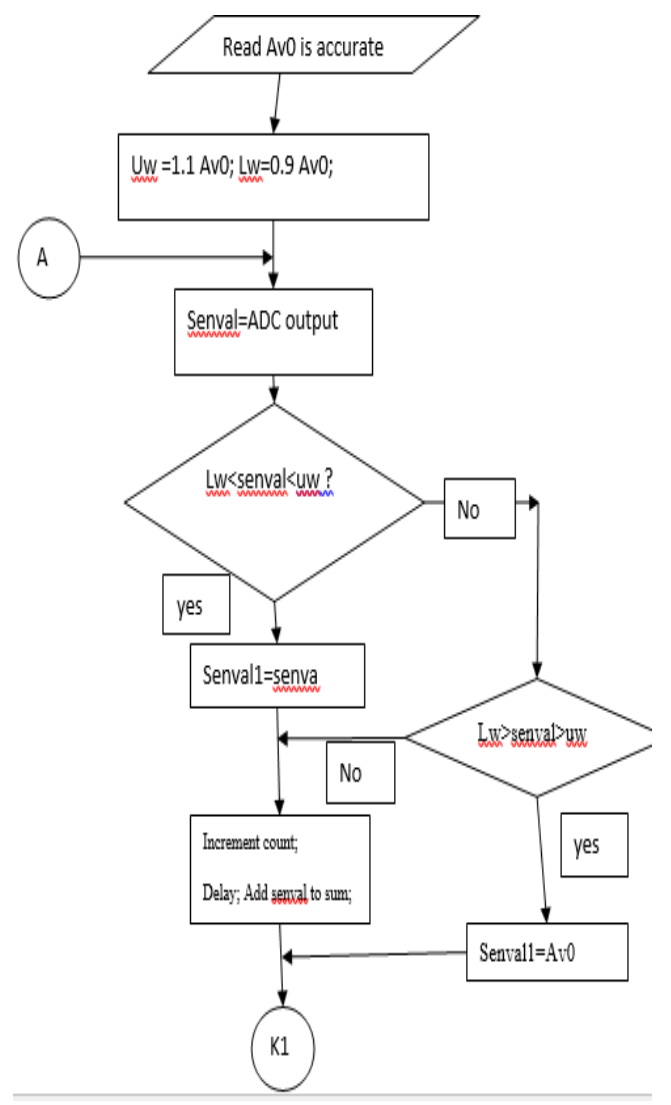

4.1 Different Load Test

The first test is caried out using different loads from $1 \mathrm{~kg}$ to $10 \mathrm{~kg}$. The net weight is measured bu subtracting the no load weight from the total weight. The digital readout is multiplied by a factor to transform it into weight in gram. The weight factor (WF) is computed to be between 6.15 and 6.2 as shown in figure (6).

Table 4.1:The weight by using weight factor(WF)

Load(g) Average K(kg) Factor
\begin{tabular}{|l|l|l|l|l|}
\hline $1000 \mathrm{~g}$ & 159.0871 & $\mathrm{~K} 1 \mathrm{~kg}=6.2858$ & $981.288(\mathrm{~g})$ & $-1.8712 \%$ \\
\hline $2000 \mathrm{~g}$ & 318.0527 & $\mathrm{~K} 2 \mathrm{~kg}=6.2882$ & $1961.825(\mathrm{~g})$ & $-1.908 \%$ \\
\hline $3000 \mathrm{~g}$ & 478.115 & $\mathrm{~K} 3 \mathrm{~kg}=6.2746$ & $2949.128(\mathrm{~g})$ & $-1.6957 \%$ \\
\hline $4000 \mathrm{~g}$ & 642.744 & $\mathrm{~K} 4 \mathrm{~kg}=6.2233$ & $3964.5992(\mathrm{~g})$ & $-0.885 \%$ \\
\hline $5000 \mathrm{~g}$ & 819.3996 & $\mathrm{~K} 5 \mathrm{~kg}=6.102$ & $5054.2533(\mathrm{~g})$ & $1.085 \%$ \\
\hline $6000 \mathrm{~g}$ & 983.66 & $\mathrm{~K} 6 \mathrm{~kg}=6.099$ & $6067.450(\mathrm{~g})$ & $1.1241 \%$ \\
\hline $7000 \mathrm{~g}$ & 1146.669 & $\mathrm{~K} 7 \mathrm{~kg}=6.1046$ & $7072.9295(\mathrm{~g})$ & $1.041 \%$ \\
\hline $8000 \mathrm{~g}$ & 1307.808 & $\mathrm{~K} 8 \mathrm{~kg}=6.1171$ & $8066.873(\mathrm{~g})$ & $0.8359 \%$ \\
& & & & \\
\hline $9000 \mathrm{~g}$ & 1475.692 & $\mathrm{~K} 9 \mathrm{~kg}=6.0988$ & $9102.4224(\mathrm{~g})$ & $1.138 \%$ \\
\hline $10000 \mathrm{~g}$ & 1642.302 & $\mathrm{~K} 10 \mathrm{~kg}=6.089$ & $10130.11289(\mathrm{~g})$ & $1.30112 \%$ \\
\hline
\end{tabular}

(Combined error is over all error).

(Accurate weight is the weight that results from operation of handling and removing the error from the signal which produced from Load cell after appling the load on it and its near by that load).

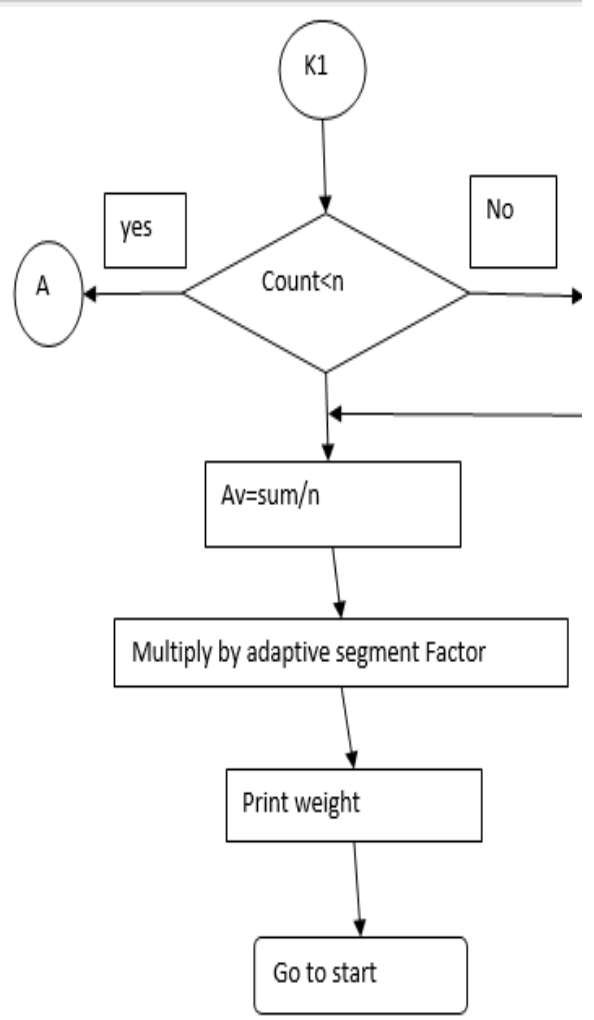

Figure (5). The main algorithm.

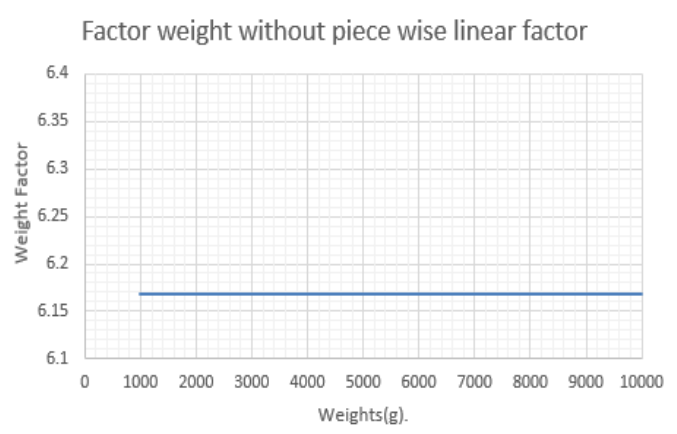

Figure (6). Using the weight factor only.

\subsection{Adaptive Weight Factor (AWF)}

To further decrease the effect of error, each load is multiplied by the required factor to eliminate the error and the outcome is illustrated in figure (7).

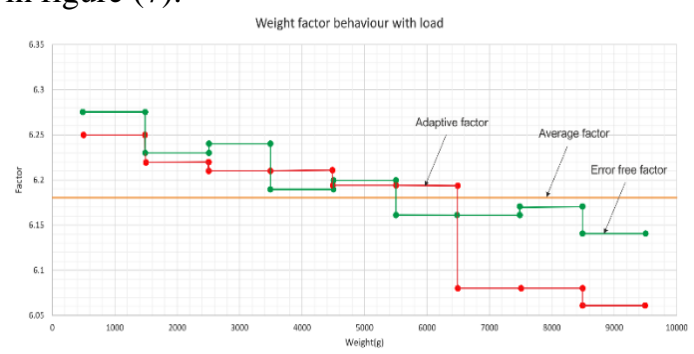

Figure (7). Error free factors 


\section{Case 1:}

Where the scale, the electronic circuit, and the scale are outside the ground box, and we use a coaxial cable to transmit the weight signal and calculate the weight for the load that is $4 \mathrm{~kg}$ as shown in figure(8) and figure(9).

Table 4.2: $4 \mathrm{~kg}$ out Box.

\begin{tabular}{|c|c|c|c|c|c|c|c|c|}
\hline & Average & sigma & max & min & wejght(g) & $\begin{array}{c}\text { combined } \\
\text { error }\end{array}$ & $\begin{array}{c}\text { improvementy } \\
\text { sigma }\end{array}$ & $\begin{array}{c}\text { on. of } \\
\text { readings }\end{array}$ \\
\hline $\begin{array}{c}\text { Before } \\
\text { Window }\end{array}$ & 642.5348 & 8.820107 & 8.820107 & 500 & 3994.01 & $\pm 0.149 \%$ & - & 100000 \\
\hline $\begin{array}{c}\text { After } \\
\text { Window }\end{array}$ & 642.5387 & 6.960909 & 722 & 592 & 3994.01 & $\pm 0.149 \%$ & $21.079 \%$ & 100000 \\
\hline
\end{tabular}

The combined error is calculated which is $\pm 0.149 \%$ from the weight $3994.01 \mathrm{~g}$, also the average and the sigma improvement is $21.079 \%$.

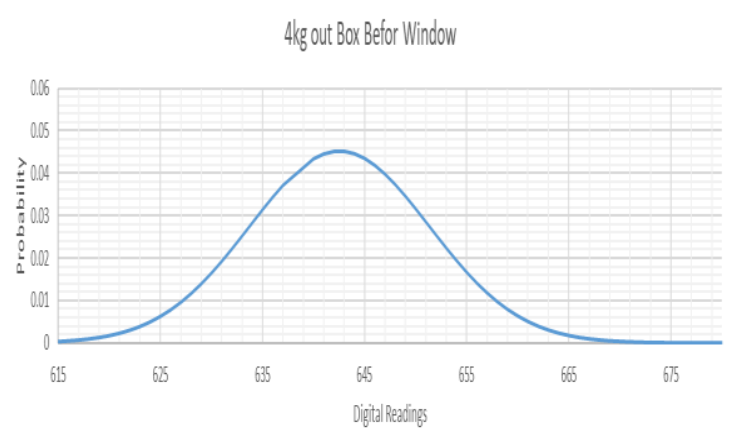

Figure (8). Out grounded box before window.

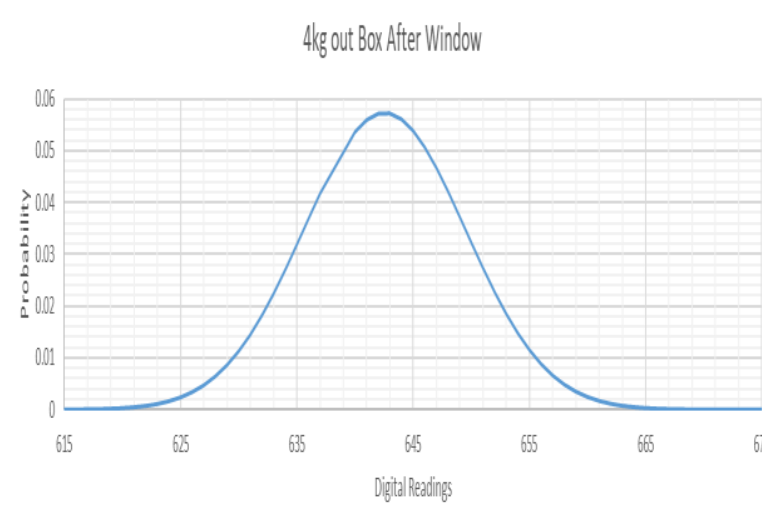

Figure (9). Out grounded box after window.

\section{Case 2:}

The same as case 1 but the electronic scale and the cct inside grounded box as shown in figure (10).
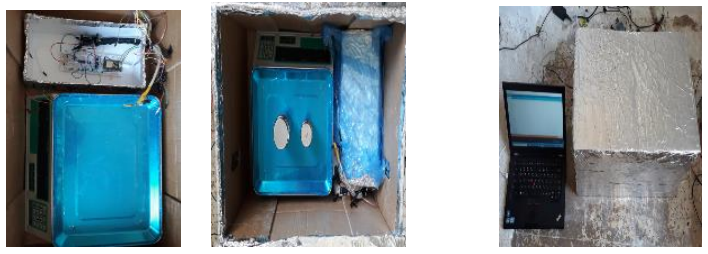

Figure (10). Grounded box.

Table 4.3: 4kg inside grounded box.

\begin{tabular}{|c|c|c|c|c|c|c|c|c|}
\hline & Average & Sigma & $\max$ & Min & Weight(g) & $\begin{array}{c}\text { Combined } \\
\text { error }\end{array}$ & $\begin{array}{c}\text { Improvement } \\
\text { sigma\% }\end{array}$ & $\begin{array}{c}\text { no. of } \\
\text { reading }\end{array}$ \\
\hline $\begin{array}{c}\text { Before } \\
\text { Window }\end{array}$ & 643.2282 & 12.45215 & 842 & 508 & 4000.23 & $\pm 0.00575 \%$ & - & 100000 \\
\hline $\begin{array}{c}\text { After } \\
\text { Window }\end{array}$ & $643 z 3243$ & 10.25584 & 734 & 603 & 4000.23 & $\pm 0.00575 \%$ & $18.195 \%$ & 100000 \\
\hline
\end{tabular}

The combined error is calculated which is $\pm 0.00575 \%$ from the weight $4000.23 \mathrm{~g}$, also the average and the sigma improvement is $18.195 \%$ as shown in figure (11) and figure (12).

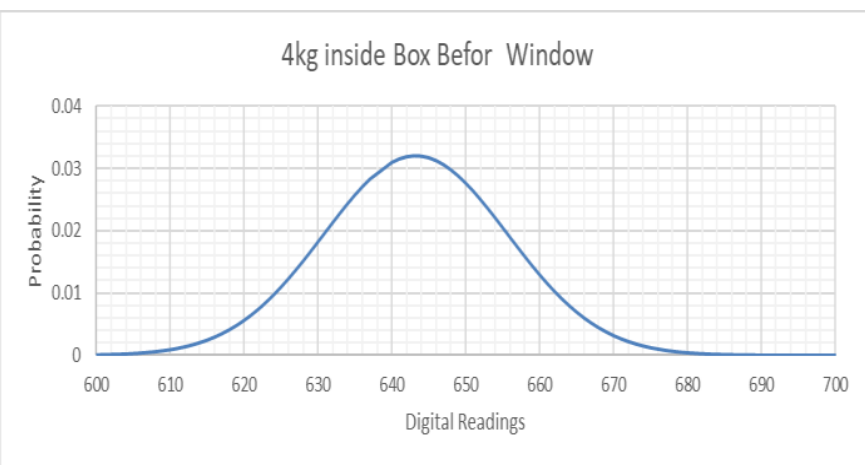

Figure (11). Inside grounded box before window.

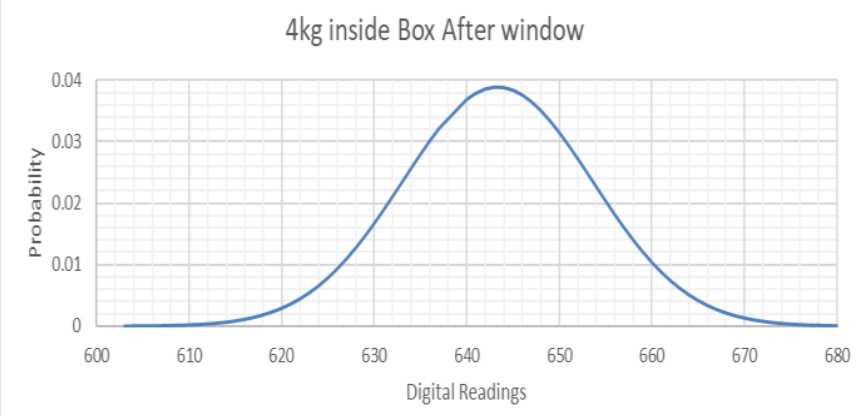

Figure (12). Inside grounded box after window. 


\section{Case 3:}

The same as case 2 but by using L.P.F as shown in figure (13) between instrumentation amplifier and ADC that is internal in the Arduino

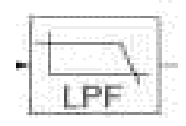

Figure (13). L.P.F [12].

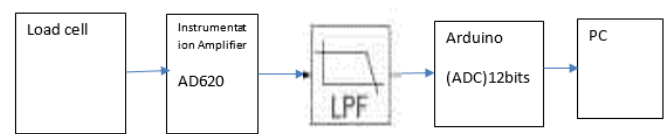

Figure (14). By using L.P.F.

Table $4.4 .4 \mathrm{~kg}$ by adding L.P.F.

\begin{tabular}{|c|c|c|c|c|c|c|c|c|}
\hline & Average & Sigma & max & min & Weight(g) & $\begin{array}{c}\text { Combined } \\
\text { error }\end{array}$ & $\begin{array}{c}\text { Sigma } \\
\text { Improvementit\% }\end{array}$ & $\begin{array}{c}\text { 10. of } \\
\text { readings }\end{array}$ \\
\hline $\begin{array}{c}\text { Before } \\
\text { Fitter }\end{array}$ & 643.1802 & 8.1733 & 864 & 480 & 4000.23 & $\pm 0.005 \%$ & - & 80000 \\
\hline After Filter & 643.1949 & 6.031435 & 724 & 594 & 4000.23 & $\pm 0.055 \%$ & $26.2 \%$ & 80000 \\
\hline
\end{tabular}

The combined error is calculated which is $\pm 0.0057 \%$ from the weight $4000.23 \mathrm{~g}$, also the average and the sigma improvement is $26.2 \%$ as shown in figure (15) and figure (16).

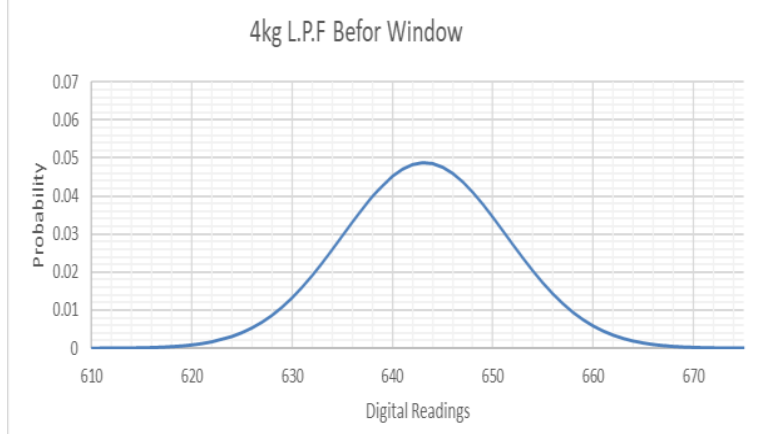

Figure (15).Using L.P.F. before window.

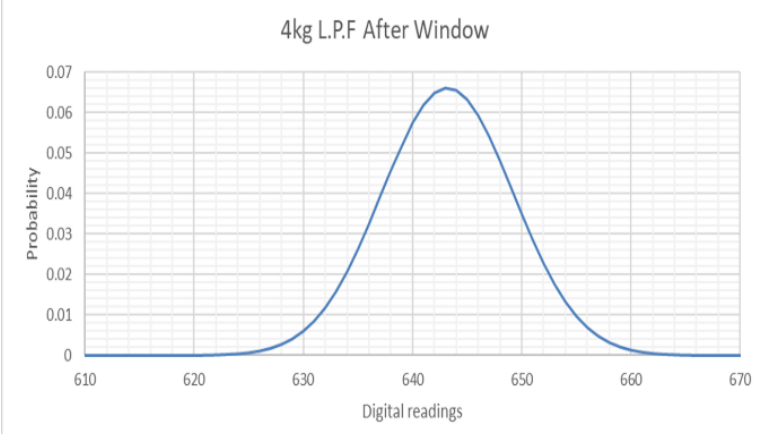

Figure (16).Using L.P.F after window.

\section{CONCLUSION}

The proposed method is used to reduce the error in weighting signal. The error is produced from load cell. The algorithm computes the accurate average of the load applied on the load cell. In which the calculated average is assigned in to one of three ranges: upper limit, lower limit and middle.This paper is discusses many techniques to handle the error in weight signal. At the begining the proposed system has used one factor for all loads, as an example $4 \mathrm{~kg}$ is measured as 3964,5992g.After repeating the reading or the measurement 100000 times to calculate the average .The combined error is $\pm 0.885 \%$ which it means that the system requires another factor to enhance it.Piece wise linear factor or adaptive factor is built using software to perform additional reduction in the error of weight signal. The piece wise factor is slightly increases in the low range load such as $1 \mathrm{~kg}$ then it will be medium value at middle such as $5 \mathrm{~kg}$. So at high range load the factor is slightly decreased.In case 1, the propsed system is out of the grounded box .For $4 \mathrm{~kg}$ the weight is $3994.01 \mathrm{~g}$ combineded with error equal to $0.149 \%$ and the sigma improvement is $21.079 \%$ after reading 100000 samples to calculate the average,In case 2, the proposed system is contained inside grounded box,the resulting weight is $4000.23 \mathrm{~g}$ combined with an error equals to $\pm 0.00575 \%$ and the sigma improvement is $18.195 \%$. In case 3 , the proposed system is contained inside grounded box and also low pass filter is connected. The weight is $4000.23 \mathrm{~g}$, containing an error equals to $\pm 0.00575 \%$ and the sigma improvement is $26.2 \%$ via reading 80000 samples to calculate average .In addition, in case 3 , the system is reached to the accurate weight faster than other cases. The speed is shown by reduction in the time by about $20 \%$ compared with case 1and case2.This improvement is produced by using low pass filter which removed the noise in the high frequencies.The proposed method used the window to reduce the noise effect that is obvious from sigma value.

\section{REFERENCES}

[1] P. Castellini, "Vibration measurements by tracking laser doppler vibrometer on automotive components," Shock and Vibration, vol. 9, no. 1-2, pp. 67-89, 2002.

[2] Frank Nicol, "Five Factors That Can Affect Your Weighing System's Accuracy", Hardy Process Solutions, 9440 Carroll Park Drive, San Diego, CA 92121, 2011. 
[3] M. Niraimathi, S.Sivakumar, R.Vigneshwaran , R.Vinothkumar , P.Babu," Automatic Bridge Control System", International Journal of Electronics and Computer Science Engineering, ISSN: 2277-1956.

[4] Ivan Müller, Carlos E. Pereira and Valner João Brusamarello ," Load cells in force sensing analysis Theory and a novel application ", IEEE Instrumentation and Measurement Magazine - March 2010.

[5] Oladimeji Ibrahim1, Sabo Miya Hassan, Abubakar Abdulkarim1, Mudathir F. Akorede1, Sulyman A.Y. Amuda," Design of Wheatstone Bridge Based Thermistor Signal Conditioning Circuit for Temperature Measurement" , Article in Journal Of Engineering Science And Technology Review, February 2019.

[6] Data sheet for AD620 Low Cost, Low Power Instrumentation Amplifier,www.analog.com.

[7] Data sheet for Arduino Nodemcu-32s Datasheet Version V1,www.Ai-thinker.com,2019.

[8] H.-W. Ma, H.-W. Fan, Q.-H. Mao, X.-H. Zhang, and W. Xing, "Noise reduction of steel cord conveyor belt defect electromagnetic signal

by combined use of improved wavelet and EMD," Algorithms, vol. 9, no. 4, article 62, 2016. View at Publisher - View at Google Scholar · View at Scopus. [9] A. Waal, S. Mercer, and B. J. Downing, "Online fruit weighing using a $500 \mathrm{MHZ}$ waveguide cavity," Electronics Letters,vol.24, no. 4, pp. 212-213, 1988.
[10] Rajesh Dey, Atreyee Biswas, Suman Kumar Laha, Amlan Pal and Dr.Achintya Das , "Signal Correction of Load Cell Output Using Adaptive Method", International Journal Of Innovative Research In Electrical,Electronics, Instrumentation And Control Engineering, Vol. 2, Issue 1, January 2014.

[11] Kyoo Nam Choi, Noise in Load Cell Signal in an Automatic Weighing System Based on a Belt Conveyor, Journal of Sensors, Article ID 1524782, 9 pages ,2017.

[12] D. Sargent, "Industrial Control Design lines", MARCH 1, 2012, 0131465112, Prentice Hall,2004. 


\section{تقليل الخطأ في الأثشارة الوزنية}

فخرالدين حامد علي

abdlkaderfares52@gmail.com
عبدالقادر فارس عبدالقادر

fhazaa@uomosul.edu.iq

جامعة الموصل ـ كلية الهنسة ـ قسم هندسة الحاسوب

يقدم البحث ويناقش كيفية استخدام بعض التقنيات لتقليل الخطا في إثارة الوزن التي تتنتج من خلية الحمل. خلية الحمل هي واحدة من أجهزة الاستشعار

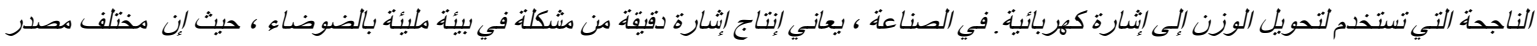

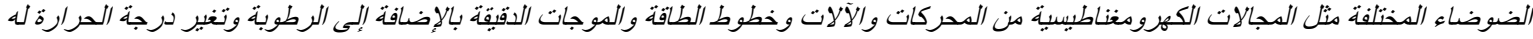
تأثيرات كبيرة على الإشارات الكهربائية الضعيفة التي تتنجها خاليا الحمل تم اعتماد كل من الفلاتتر والبرامج لتقليل الثأثيرات غير المطلوبة.

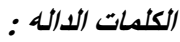

خلية الحمل، الارنوينو، محول الإشارة التناظرية الى رقمية ، أداة النكبير. 